\title{
Dental avulsion management by emergency professionals and efficacy of education
}

\author{
Gerenciamento de avulsão dentária por profissionais de emergência e eficácia da educação \\ Manejo de la avulsión dental por profesionales de emergencias y eficacia de la educación
}

Received: 03/29/2021 | Reviewed: 04/03/2021 | Accept: 04/05/2021 | Published: 04/16/2021

\author{
Carolina dos Santos Santinoni \\ ORCID: https://orcid.org/0000-0001-5153-2419 \\ Universidade do Oeste Paulista, Brazil \\ E-mail: carolsantinoni@msn.com \\ Gabriela Sumie Yaguinuma Gonçalves \\ ORCID: https://orcid.org/0000-0001-5120-3172 \\ Universidade do Oeste Paulista, Brazil \\ E-mail: gabisumie@hotmail.com \\ Belquis Alves dos Santos \\ ORCID: https://orcid.org/0000-0003-0945-7392 \\ Universidade do Oeste Paulista, Brazil \\ E-mail: bell-alves@live.com \\ Sheyla Adriane Rodrigues Oliveira João \\ ORCID: https://orcid.org/0000-0002-7227-0734 \\ Universidade do Oeste Paulista, Brazil \\ E-mail: sheylaadriane@hotmail.com \\ Juliane Avansini Marsicano \\ ORCID: https://orcid.org/0000-0002-8213-1754 \\ Universidade do Oeste Paulista, Brazil \\ E-mail: juliane@unoeste.br \\ Rosana Leal do Prado \\ ORCID: https://orcid.org/0000-0002-5897-2799 \\ Universidade do Oeste Paulista, Brazil \\ E-mail: rosana@unoeste.br \\ Graziela Garrido Mori \\ ORCID: https://orcid.org/0000-0002-8690-5294 \\ Universidade do Oeste Paulista, Brazil \\ E-mail: graziela@unoeste.br
}

\begin{abstract}
This intervention study evaluated knowledge of first responders regarding the emergency clinical protocol in cases of dental avulsions and impact of an informative campaign. A questionnaire was applied to evaluate effect of provided information on knowledge among emergency service professionals regarding the management of avulsion of teeth: before campaign (T0) and after campaign (T1). Participants were invited to attend the dental trauma awareness campaign that was carried out by the researchers. The campaign addressed main doubts and difficulties regarding emergency dental trauma care. Data were statistically analyzed $(\mathrm{p}<0.05)$. There was significant increasing in the knowledge of professionals regarding the possibility (from 74\% to 88\%) and ability (5\% to 32\%) of first responders perform tooth replantation; about the ideal time to perform the replantation (from 30\% to 59\%); about the correct handling (from 52\% to 85\%) and the need for cleaning (from $60 \%$ to $79 \%$ ) of an avulsed tooth for replantation. It can be concluded there is a lack of knowledge of emergency service professionals about tooth avulsion management. The strong message is the importance not only of identifying the lack of knowledge of the professionals about tooth injuries, but also perform the education that can significantly improve the professional knowledge.
\end{abstract}

Keywords: Tooth injuries; First aid; Tooth avulsion; Health education.

\section{Resumo}

Este estudo de intervenção avaliou o conhecimento de socorristas em relação ao protocolo clínico de emergência em casos de avulsões dentárias e impacto de uma campanha informativa. Um questionário foi aplicado para avaliar o efeito das informações fornecidas sobre o conhecimento dos profissionais do serviço de emergência quanto ao manejo da avulsão dentária: antes da campanha (T0) e após a campanha (T1). Os participantes foram convidados a participar da campanha de conscientização sobre traumas dentais realizada pelos pesquisadores. A campanha abordou as principais dúvidas e dificuldades relacionadas ao atendimento emergencial do traumatismo dentário. Os dados foram analisados estatisticamente $(\mathrm{p}<0,05)$. Houve aumento significativo no conhecimento dos profissionais quanto à possibilidade (de $74 \%$ para $88 \%$ ) e capacidade (5\% para $32 \%$ ) dos primeiros respondentes realizarem reimplantes; sobre o momento ideal para realizar o reimplante (de $30 \%$ a $59 \%$ ); sobre o manuseio correto (de $52 \%$ a $85 \%$ ) e a 
necessidade de limpeza (de 60\% a 79\%) de um dente avulsionado para reimplante. Pode-se concluir que há baixo conhecimento dos profissionais dos serviços de emergência sobre o manejo da avulsão dentária. A mensagem forte é a importância de não só identificar a falta de conhecimento dos profissionais sobre traumatismo dentário, mas também realizar a educação que pode melhorar significativamente o conhecimento profissional.

Palavras-chave: Traumatismos dentários; Primeiros socorros; Avulsão dentária; Educação em saúde.

\section{Resumen}

Este estudio de intervención evaluó el conocimiento de los socorristas sobre el protocolo clínico de emergencia en casos de avulsiones dentales y el impacto de una campaña informativa. Se aplicó un cuestionario para evaluar el efecto de la información proporcionada sobre el conocimiento entre los profesionales de los servicios de emergencia sobre el manejo de la avulsión de dientes: antes de la campaña (T0) y después de la campaña (T1). Los participantes fueron invitados a asistir a la campaña de concientización sobre el trauma dental que llevaron a cabo los investigadores. La campaña abordó las principales dudas y dificultades relacionadas con la atención urgente de traumatismos dentales. Los datos se analizaron estadísticamente $(\mathrm{p}<0,05)$. Hubo un aumento significativo en el conocimiento de los profesionales con respecto a la posibilidad (del $74 \%$ al $88 \%$ ) y la capacidad (del $5 \%$ al $32 \%$ ) de los socorristas para realizar la reimplantación dentaria; sobre el momento ideal para realizar la replantación (del 30\% al 59\%); sobre el manejo correcto (del 52\% al 85\%) y la necesidad de limpieza (del 60\% al 79\%) de un diente avulsionado para su reimplantación. Se puede concluir que existe una falta de conocimiento de los profesionales de los servicios de emergencia sobre el manejo de la avulsión dental. El mensaje contundente es la importancia no solo de identificar el desconocimiento de los profesionales sobre las lesiones dentales, sino también de realizar la educación que pueda mejorar significativamente el conocimiento profesional.

Palabras clave: Traumatismos de los dientes; Primeros auxílios; Avulsión de diente; Educación en salud.

\section{Introduction}

Dental trauma is a set of external impact that affects the teeth and surrounding tissues, which can be a simple enamel fracture until the definitive loss of the dental element, being classified into dental injuries, support tissue injuries, tissue injuries, soft and bone tissue lesions (Gonçalves et al., 2017). Recently, Petti et al. (Petti et al., 2018) performed a study to estimate global prevalence and incidence of dental trauma and concluded that more than one billion living people have had dental trauma. In Brazil, the prevalence ranges from $9.4 \%$ to $41.6 \%$, with preschool children being the most affected (Gonçalves et al., 2017).

Facial injuries are six times more likely to happen in fast and contact sports compared to workplace accidents and three times more than exposure to violence or traffic accidents, causing orofacial trauma (Petrović et al., 2016).

During sports activities, traffic accidents and fights, adolescents may suffer dental trauma, representing a serious social problem. These traumas affect only a single tooth, or in the most severe cases involve multiple teeth. Fracture of the crown of the dental element of the anterior teeth, especially the central incisors are the most affected, causing pain and discomfort for patients and can significantly affect the quality of life by affecting the smile. And the anterior teeth are not only important for aesthetics, but also for speech, chewing, the health of adjacent tissues and the individual's own psychological health (Azami-Aghdash et al., 2015; Goyal et al., 2017).

In enamel and dentin fractures without pulp exposure, urgent care is not necessary. However, dental care is necessary to evaluate and treat the case (Andersson et al., 2016). Other moderate injuries such as coronary fractures with pulp exposure, intrusive dislocation, concussion, subluxation, and trauma to primary teeth require immediate professional dental care that cannot be performed at the accident site (Andersson et al., 2016). Dental avulsion, although considered a more serious situation, should also receive immediate attention but this management can be performed in the accident site by anyone (Andersson et al., 2016).

Among dental trauma types, greater attention should be paid to dental avulsion when the dental element comes out of the socket completely, as the chances of tooth preservation depend directly on care at the time and place of the accident. In permanent teeth, immediate reimplantation of the tooth in the socket, performed by anyone, even the victim, within the first 5 
minutes after trauma is indicate (Andersson et al., 1990; Baginska et al., 2016). Cells in the periodontal ligament can necrosate after 30-60 minutes if stored in a dry medium, which significantly reduces the favorable prognosis of dental replantation. If immediate reimplantation is not possible, to avoid dehydration of the tooth, the best way to store this avulsed tooth is in substances closest to the saliva Ph, like the victim's own saliva or milk (Mori et al., 2007; Mori et al., 2010). Some natural substances have also been study and demonstrated good storage medium such as propolis (Mori et al., 2010). This storage time have to be only the needed time to take it to the dentist. Some rules must also be followed to prevent crushing of periodontal ligament cells on the root surface: the dirty tooth should be washed with running water or saline solution, not rubbing the tooth or root, always manipulating the tooth by the crown, and routing the fastest possible victim for the dentist (Mori et al., 2007).

Avulsed teeth that are stored in the wet environment until replantation can present greater chances of success, but if the tooth is kept stored in dry medium before the replantation, there is no maintenance of the cell viability making the prognosis unfavorable (Mori et al., 2007). Post-replantation complications may occur as dental pulp necrosis, dental ankylosis, root resorption, failure of complete root development, and in more severe cases dental loss (Matias et al., 2014).

Twenty-four-hour emergency services are most often referred to dental trauma while dentists rarely provide first aid (Cruz-da-Silva et al., 2016). Therefore, these professionals need to know the protocol of dental trauma, but studies show inadequate professional knowledge on this subject, and after campaigns and lectures contribute significantly to increase knowledge of these professionals (Cruz-da-Silva et al., 2016).

Reliable data related to the prevalence, causes and risk factors of traumatic dental injuries are needed for its prevention. However, many people are unaware of these risk factors and the main ways to prevent these injuries. Moreover, some dentists and health professionals do not attach much importance to prevention but are more concerned with aspects of treatment (Ain et al., 2016). Thus, to increase the chances of a favorable prognosis in cases of dental trauma, it is essential to provide proper guidance to first-aid professionals about the importance of knowing the immediate clinical protocol and thus, it is possible to save more teeth, besides reduce emotional and psychological impacts on individuals affected by dental trauma.

Importance not only identifying the lack of knowledge of the population about the conducts to be performed in case of dental trauma, but also of the education of the emergency professionals about this topic.

This intervention study evaluated knowledge of first responders regarding the emergency clinical protocol in cases of dental avulsions and impact of an informative campaign.

\section{Methodology}

This study was carried out through a longitudinal analysis of the knowledge of all professionals involved in emergency care (firefighters and professionals of the municipal mobile emergency service) about dental trauma in the city of Presidente Prudente, SP, Brazil.

Inclusion criteria involved professionals who provide first aid in the emergency services in the city of Presidente Prudente (population of 100 professionals). Exclusion criteria involved professionals who did not attend to the lecture about dental traumatism.

The research was approved by the Research Ethics Committee of the University of Western Sao Paulo - Unoeste (protocol 90985518.8.0000.5515). The professionals involved in emergency care (firefighters and professionals of the municipal mobile emergency service) only participated of the research after a thorough explanation of their objectives from reading the Letter of Clarification to the patient and signing the Informed Consent Form (FICT). This term included a description of how the first responder would be analyzed, ensuring the confidentiality of the information and disallowing any form of coercion or pressure for their voluntary participation. 
All participants received information about the objective procedures of the study. A questionnaire was applied twice to evaluate the effect of the information provided on knowledge and changes in attitudes among non-dentists' health care regarding tooth avulsion management: before the lecture (T0) and after the lecture (T1).

The purpose of the first questionnaire application (T0) was to determine a priori knowledge about the subject. The purpose of the second questionnaire application (T1) was to determine improvements in knowledge and to evaluate the influence of the information provided.

The questionnaire (Table 1) contained subjective questions about the definition of tooth avulsion / replantation, postavulsion management, extra-alveolar time, and storage media of tooth. The questions were partly derived from previously published research (Matias et al., 2014; Cruz-da-Silva et al., 2016).

The questionnaire was divided into two sections. The first section comprises items about personal information (gender and age) and the concept of tooth avulsion. The second section consisted of 12 (twelve) multiple choice questions addressing knowledge on dental avulsion, training received on this subject, and management of avulsion cases.

Participants were invited to participate in the information campaign about dental trauma that was carried out by the Dental Trauma Extension Project of the University. The campaign addressed the main doubts and difficulties regarding urgent care. The campaign included lectures and the use of printed materials containing information on the urgent care for dental trauma, especially dental avulsion. Participants were instructed on immediate replantation, on the appropriate way of washing the avulsed tooth, as well as the means of preservation for this tooth and posttraumatic conducts. Participants were encouraged to discuss their questions and collaborate with everyone's knowledge and learning.

For data analysis, chi-square test was used, with a significance level of 5\% (R Foundation for Statistical Computing, Vienna, Austria. URL https://www.R-project.org/.).

\section{Results}

One hundred emergency professionals (100\% of the emergency professional population) answered the questionnaire at T0. A difficulty in accessing professionals who worked on an hourly scale was observed at T1. So, seventy-tree emergency professionals answered the questionnaire after campaign.

Tables 1 and 2 show percentage of each item answered by the professionals before (T0) (Table 1) and after (T1) (Table 2) the campaign. The desired/acceptable answers to each question are highlighted in blue. Figures 1 and 2 show a comparative analysis of the percentages of responses obtained before and after the campaign.

There was a significant increase in the knowledge of professionals regarding the possibility (from $74 \%$ to $88 \%$; $\mathrm{p}$ value $=0.04348)$ and ability $(5 \%$ to $32 \% ; p$-value $=0.00000797)$ to replant an avulsed tooth; about the ideal time to perform the replantation (from $30 \%$ to $59 \%$; $p$-value $=0.01488$ ) or the appropriate storage medium until the patient can be in front of a specialized professional ( $\mathrm{p}$-value $=0.0001991)$; about the correct handling (from $52 \%$ to $85 \%$; $\mathrm{p}$-value $=0.00001361$ ) and the need for cleaning (from $60 \%$ to $79 \%$; p-value $=0.01083$ ) of an avulsed tooth before replantation.

No significant difference was observed only in relation to the referral of the appropriate professional to provide emergency care, if it cannot be performed immediately by the emergency attendant ( $\mathrm{p}$-value $=0.1762$ ). 
Research, Society and Development, v. 10, n. 4, e42210414393, 2021

(CC BY 4.0) | ISSN 2525-3409 | DOI: http://dx.doi.org/10.33448/rsd-v10i4.14393

Table 1 - Percentage observed of each item answered by first responders, BEFORE the campaign on dental trauma was carried out.

\begin{tabular}{|c|c|c|c|c|c|c|c|}
\hline Questions & \multicolumn{7}{|c|}{ Results } \\
\hline 1. Do you know what tooth avulsion is? & $\begin{array}{l}84 \% \\
\text { Yes }\end{array}$ & $\begin{array}{l}16 \% \\
\text { No }\end{array}$ & & & & & \\
\hline $\begin{array}{l}\text { 2. In your career as first responder, have you } \\
\text { seen any cases of dental avulsion? }\end{array}$ & $\begin{array}{l}58 \% \\
\text { Yes }\end{array}$ & $\begin{array}{l}42 \% \\
\text { No }\end{array}$ & & & & & \\
\hline 3. Do you know what dental replanting means? & $\begin{array}{l}85 \% \\
\text { Yes }\end{array}$ & $\begin{array}{l}15 \% \\
\text { No }\end{array}$ & & & & & \\
\hline $\begin{array}{l}\text { 4. In your opinion, is it possible to reposition } \\
\text { (replantation) an avulsed permanent tooth back } \\
\text { in its socket? }\end{array}$ & $\begin{array}{l}74 \% \\
\text { Yes }\end{array}$ & $\begin{array}{l}26 \% \\
\text { No }\end{array}$ & & & & & \\
\hline $\begin{array}{l}\text { 5. If you answered "Yes" in the previous } \\
\text { question, what would be the ideal time to } \\
\text { perform this repositioning (replantation), in } \\
\text { order to obtain good results? If you answered } \\
\text { "No", ignore this question. }\end{array}$ & $\begin{array}{l}11 \% \\
\text { Immediately } \\
\text { after trauma }\end{array}$ & $\begin{array}{l}17 \% \\
\text { Up to } 30 \\
\text { minutes after } \\
\text { trauma }\end{array}$ & $\begin{array}{l}11 \% \\
1 \text { to } 2 \text { hours } \\
\text { after the } \\
\text { trauma }\end{array}$ & $\begin{array}{l}4 \% \\
2 \text { to } 6 \text { hours } \\
\text { after the } \\
\text { trauma }\end{array}$ & $\begin{array}{l}\qquad 1 \% \\
24 \text { to } 72 \\
\text { hours after } \\
\text { the trauma }\end{array}$ & $\begin{array}{c}56 \% \\
\text { I } \\
\text { don'tknow }\end{array}$ & \\
\hline $\begin{array}{l}\text { 6. When you find an avulsed tooth from the floor } \\
\text { you: }\end{array}$ & $\begin{array}{l}5 \% \\
\text { You can pick } \\
\text { up the tooth } \\
\text { anywhere }\end{array}$ & $\begin{array}{l}52 \% \\
\text { You should } \\
\text { preferably } \\
\text { take it by the } \\
\text { crown }\end{array}$ & $\begin{array}{l}0 \% \\
\text { You must } \\
\text { catch it } \\
\text { preferably in } \\
\text { the root }\end{array}$ & $\begin{array}{c}0 \% \\
\text { You } \\
\text { shouldnot } \\
\text { pick it up off } \\
\text { the floor }\end{array}$ & $\begin{array}{c}43 \% \\
\text { I } \\
\text { donotknow }\end{array}$ & & \\
\hline $\begin{array}{l}\text { 7. In a situation like this, do you consider } \\
\text { yourself able to reposition (perform } \\
\text { replantation of) the tooth back in its socket? }\end{array}$ & $\begin{array}{l}5 \% \\
\text { Yes }\end{array}$ & $\begin{array}{l}95 \% \\
\text { No }\end{array}$ & & & & & \\
\hline $\begin{array}{l}\text { 8. In case you are unable to reposition the tooth } \\
\text { in the socket, where should it preferably be } \\
\text { stored until the patient can be in front of a } \\
\text { specialized professional? }\end{array}$ & $\begin{array}{l}\quad 4 \% \\
\text { Wrapped in a } \\
\text { paper napkin }\end{array}$ & $\begin{array}{l}0 \% \\
\text { In a container } \\
\text { with tap water }\end{array}$ & $\begin{array}{l}\quad 42 \% \\
\text { In a container } \\
\text { with saline } \\
\text { solution }\end{array}$ & $\begin{array}{l}\text { 7\% } \\
\text { In a } \\
\text { container } \\
\text { with milk }\end{array}$ & $\begin{array}{l}12 \% \\
\text { On ice }\end{array}$ & $\begin{array}{l}0 \% \\
\text { In some } \\
\text { other } \\
\text { substance }\end{array}$ & $\begin{array}{l}35 \% \\
\text { I } \\
\text { donotk } \\
\text { now }\end{array}$ \\
\hline
\end{tabular}


Research, Society and Development, v. 10, n. 4, e42210414393, 2021

(CC BY 4.0) | ISSN 2525-3409 | DOI: http://dx.doi.org/10.33448/rsd-v10i4.14393

\begin{tabular}{|c|c|c|c|c|c|c|}
\hline $\begin{array}{l}\text { 9. If that tooth fell on the floor and became } \\
\text { dirty, you should: }\end{array}$ & $\begin{array}{l}9 \% \\
\text { Wash it under } \\
\text { running tap } \\
\text { water }\end{array}$ & $\begin{array}{c}6 \% \\
\text { Wash it in } \\
\text { milk }\end{array}$ & $\begin{array}{c}45 \% \\
\text { Wash it with } \\
\text { saline solution }\end{array}$ & $\begin{array}{l}2 \% \\
\text { Brush it, } \\
\text { clean the } \\
\text { crown and } \\
\quad \text { root }\end{array}$ & $\begin{array}{c}5 \% \\
\text { Donotwash }\end{array}$ & $\begin{array}{c}33 \% \\
\text { I } \\
\text { donotknow }\end{array}$ \\
\hline $\begin{array}{l}\text { 10. If you are unable to undergo treatment at } \\
\text { the accident site, what would be the best first } \\
\text { aid facility to refer a patient with this type of } \\
\text { trauma? }\end{array}$ & $\begin{array}{c}69 \% \\
\text { Publichospital }\end{array}$ & $\begin{array}{l}12 \% \\
\text { The dentist } \\
\text { closest to the } \\
\text { accident site }\end{array}$ & $\begin{array}{c}4 \% \\
\text { Patientownpri } \\
\text { vatedentist }\end{array}$ & $\begin{array}{c}0 \% \\
\text { The } \\
\text { SchoolofDen } \\
\text { tistry }\end{array}$ & $\begin{array}{c}14 \% \\
\text { A } \\
\text { specialized } \\
\text { dentist }\end{array}$ & $\begin{array}{c}1 \% \\
\text { Somewher } \\
\text { eelse }\end{array}$ \\
\hline $\begin{array}{l}\text { 11. Have you ever received any instructions on } \\
\text { what to do in situations like these? }\end{array}$ & $\begin{array}{l}19 \% \\
\text { Yes }\end{array}$ & $\begin{array}{c}81 \% \\
\text { No }\end{array}$ & & & & \\
\hline $\begin{array}{l}\text { 12. Do you think this type of information is } \\
\text { important and necessary for a first responder? }\end{array}$ & $\begin{array}{l}97 \% \\
\text { Yes }\end{array}$ & $\begin{array}{l}3 \% \\
\text { No }\end{array}$ & & & & \\
\hline
\end{tabular}

Source: Authors. 
Table 2 - Percentage of each item answered by first responders, AFTER the campaign on dental trauma

\begin{tabular}{|c|c|c|c|c|c|c|c|}
\hline \multirow{2}{*}{$\begin{array}{l}\text { Questions } \\
\text { 1. Do you know what tooth avulsion is? }\end{array}$} & \multicolumn{7}{|c|}{ Results } \\
\hline & $\begin{array}{l}85 \% \\
\text { Yes }\end{array}$ & $\begin{array}{c}15 \% \\
\text { No }\end{array}$ & & & & & \\
\hline $\begin{array}{l}\text { 2. In your career as first responder, have you } \\
\text { seen any cases of dental avulsion? }\end{array}$ & $\begin{array}{l}48 \% \\
\text { Yes }\end{array}$ & $\begin{array}{l}52 \% \\
\text { No }\end{array}$ & & & & & \\
\hline $\begin{array}{l}\text { 3. Do you know what dental replanting } \\
\text { means? }\end{array}$ & $\begin{array}{l}92 \% \\
\text { Yes }\end{array}$ & $\begin{array}{l}8 \% \\
\text { No }\end{array}$ & & & & & \\
\hline $\begin{array}{l}\text { 4. In your opinion, is it possible to reposition } \\
\text { (replantation) an avulsed permanent tooth } \\
\text { back in its socket? }\end{array}$ & $\begin{array}{l}88 \% \\
\text { Yes }\end{array}$ & $\begin{array}{l}12 \% \\
\text { No }\end{array}$ & & & & & \\
\hline $\begin{array}{l}\text { 5. If you answered "Yes" in the previous } \\
\text { question, what would be the ideal time to } \\
\text { perform this repositioning (replantation), in } \\
\text { order to obtain good results? If you answered } \\
\text { "No", ignore this question. }\end{array}$ & $\begin{array}{l}21 \% \\
\text { Immediately } \\
\text { after trauma }\end{array}$ & $\begin{array}{l}22 \% \\
\text { Up to } 30 \\
\text { minutes after } \\
\text { trauma }\end{array}$ & $\begin{array}{c}16 \% \\
1 \text { to } 2 \text { hours } \\
\text { after the trauma }\end{array}$ & $\begin{array}{l}8 \% \\
2 \text { to } 6 \text { hours } \\
\text { after the } \\
\text { trauma }\end{array}$ & $\begin{array}{l}3 \% \\
24 \text { to } 72 \\
\text { hours after } \\
\text { the trauma }\end{array}$ & $\begin{array}{l}30 \% \\
\text { I } \\
\text { don'tkn } \\
\text { ow }\end{array}$ & \\
\hline $\begin{array}{l}\text { 6. When you find an avulsed tooth from the } \\
\text { floor you: }\end{array}$ & $\begin{array}{l}4 \% \\
\text { You can pick up } \\
\text { the tooth } \\
\text { anywhere on it }\end{array}$ & $\begin{array}{l}85 \% \\
\text { You should } \\
\text { preferably take } \\
\text { it by the crown }\end{array}$ & $\begin{array}{l}1 \% \\
\text { You must catch } \\
\text { it preferably in } \\
\text { the root }\end{array}$ & $\begin{array}{l}0 \% \\
\text { You should } \\
\text { not pick it up } \\
\text { off the floor }\end{array}$ & $\begin{array}{c}10 \% \\
\text { I do } \\
\text { notknow }\end{array}$ & & \\
\hline $\begin{array}{l}\text { 7. In a situation like this, do you consider } \\
\text { yourself able to reposition (perform } \\
\text { replantation of) the tooth back in its socket? }\end{array}$ & $\begin{array}{l}32 \% \\
\text { Yes }\end{array}$ & $\begin{array}{l}68 \% \\
\text { No }\end{array}$ & & & & & \\
\hline $\begin{array}{l}\text { 8. In case you are unable to reposition the } \\
\text { tooth in the socket, where should it preferably } \\
\text { be stored until the patient can be in front of a } \\
\text { specialized professional? }\end{array}$ & $\begin{array}{l}\quad 6 \% \\
\text { Wrapped in a } \\
\text { paper napkin }\end{array}$ & $\begin{array}{l}0 \% \\
\text { In a container } \\
\text { with tap water }\end{array}$ & $\begin{array}{l}30 \% \\
\text { In a container } \\
\text { with saline } \\
\text { solution }\end{array}$ & $\begin{array}{l}\quad 48 \% \\
\text { In a container } \\
\text { with milk }\end{array}$ & $\begin{array}{l}4 \% \\
\text { On ice }\end{array}$ & $\begin{array}{c}0 \% \\
\text { In } \\
\text { some } \\
\text { othersu } \\
\text { bstance }\end{array}$ & $\begin{array}{c}12 \% \\
\text { I do } \\
\text { notkno } \\
\text { w }\end{array}$ \\
\hline
\end{tabular}


Research, Society and Development, v. 10, n. 4, e42210414393, 2021

(CC BY 4.0) | ISSN 2525-3409 | DOI: http://dx.doi.org/10.33448/rsd-v10i4.14393

\begin{tabular}{|c|c|c|c|c|c|c|}
\hline $\begin{array}{l}\text { 9. If that tooth fell on the floor and became } \\
\text { dirty, you should: }\end{array}$ & $\begin{array}{l}22 \% \\
\text { Wash it under } \\
\text { running tap } \\
\text { water }\end{array}$ & $\begin{array}{l}19 \% \\
\text { Wash it in milk }\end{array}$ & $\begin{array}{c}38 \% \\
\text { Wash it with } \\
\text { saline solution }\end{array}$ & $\begin{array}{l}3 \% \\
\text { Brush it, clean } \\
\text { the crown and } \\
\text { root }\end{array}$ & $\begin{array}{c}4 \% \\
\text { Do } \\
\text { notwash }\end{array}$ & $\begin{array}{l}14 \% \\
\text { I do } \\
\text { notkno } \\
\text { w }\end{array}$ \\
\hline $\begin{array}{l}\text { 10. If you are unable to undergo treatment at } \\
\text { the accident site, what would be the best first } \\
\text { aid facility to refer a patient with this type of } \\
\text { trauma? }\end{array}$ & $\begin{array}{c}59 \% \\
\text { Public hospital }\end{array}$ & $\begin{array}{l}21 \% \\
\text { The dentist } \\
\text { closest to the } \\
\text { accident site }\end{array}$ & $\begin{array}{c}4 \% \\
\text { Patientownpriva } \\
\text { tedentist }\end{array}$ & $\begin{array}{c}1 \% \\
\text { The } \\
\text { SchoolofDenti } \\
\text { stry }\end{array}$ & $\begin{array}{c}15 \% \\
\text { A } \\
\text { specialized } \\
\text { dentist }\end{array}$ & $\begin{array}{l}0 \% \\
\text { Somew } \\
\text { hereels } \\
\text { e }\end{array}$ \\
\hline $\begin{array}{l}\text { 11. Have you ever received any instructions } \\
\text { on what to do in situations like these? }\end{array}$ & $\begin{array}{l}45 \% \\
\text { Yes }\end{array}$ & $\begin{array}{l}55 \% \\
\text { No }\end{array}$ & & & & \\
\hline $\begin{array}{l}\text { 12. Do you think this type of information is } \\
\text { important and necessary for afirst responder? }\end{array}$ & $\begin{array}{l}99 \% \\
\text { Yes }\end{array}$ & $\begin{array}{l}1 \% \\
\text { No }\end{array}$ & & & & \\
\hline
\end{tabular}

Source: Authors. 
Figure 1. Knowledge of first responders about the possibility and ability to perform the replantation of an avulsed tooth, before and after the campaign.

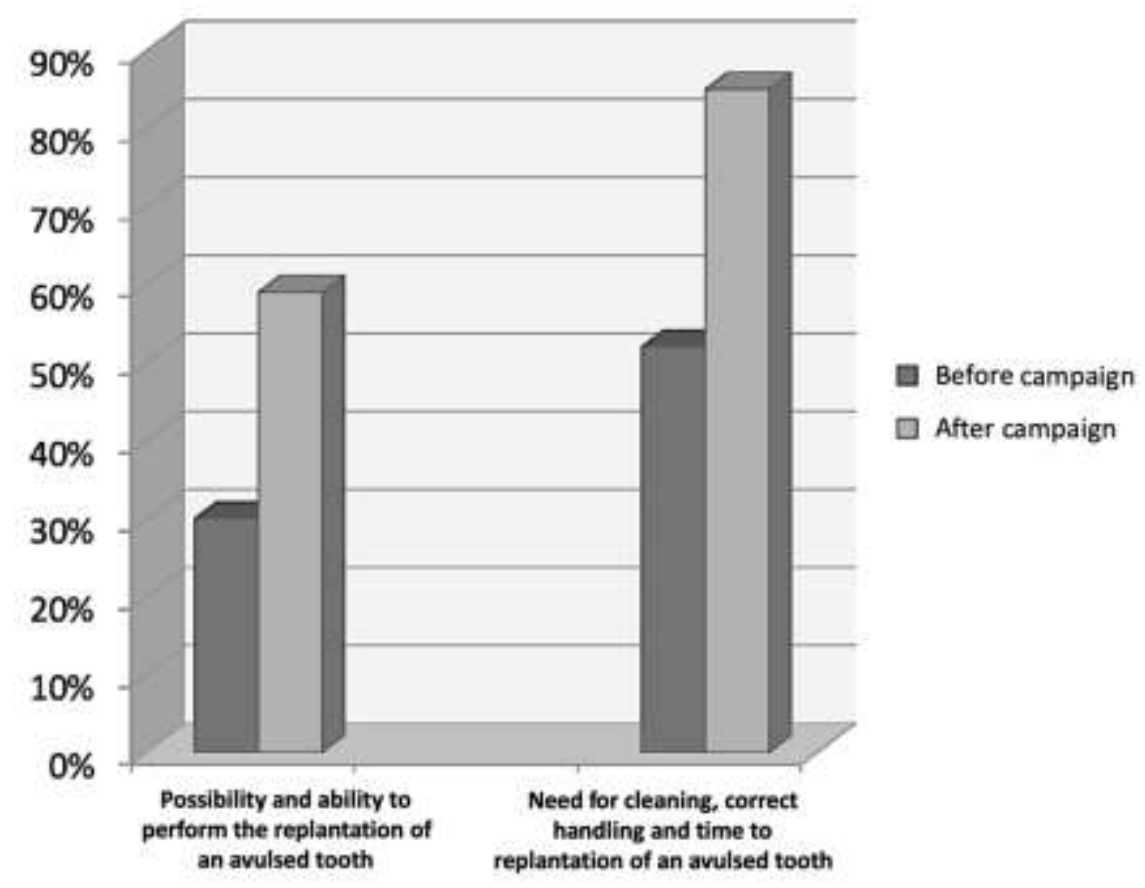

Source: Authors.

Figure 2. Knowledge of first responders about the need for cleaning, correct handling and time for replantation of an avulsed tooth, before and after the campaign.

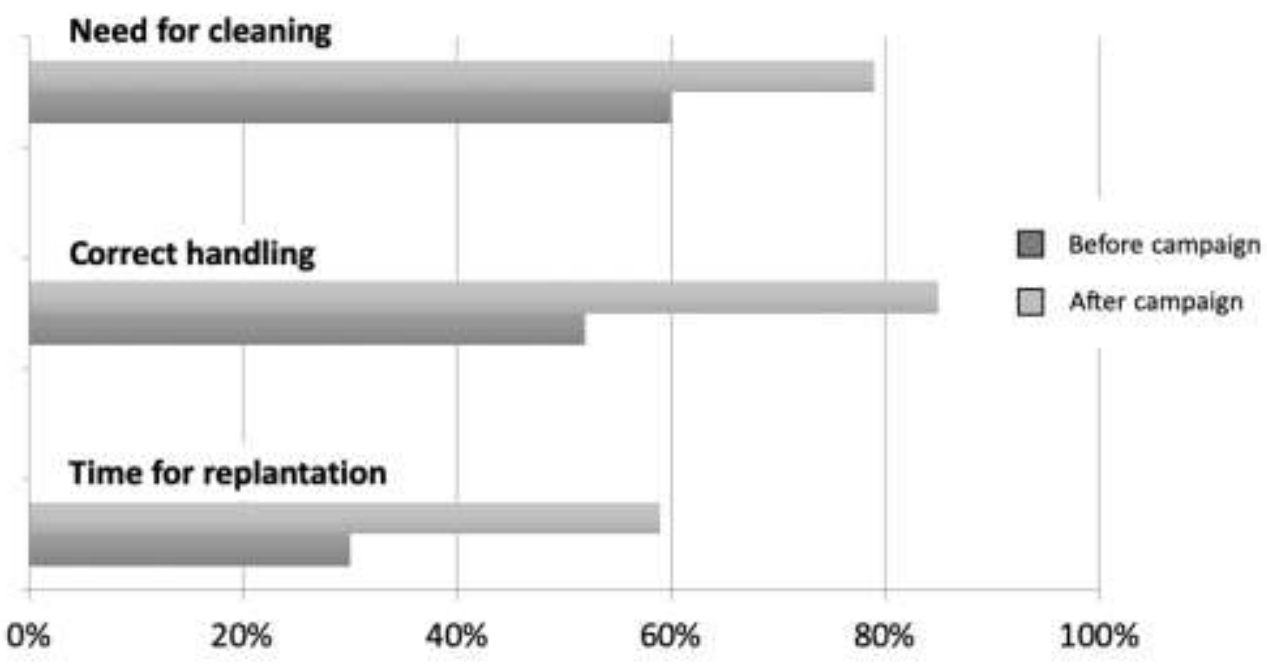

Source: Authors. 


\section{Discussion}

Recent literature has shown that first responders have inadequate knowledge about how to act in cases of dental traumatism, including tooth avulsion (Cruz-da-Silva et al., 2016). In fact, the results of the present study showed that professionals involved in emergency care (firefighters and municipal emergency mobile service professionals) provided unsatisfactory answers to the questionnaire applied before the informative campaign. Other professionals strictly related to dental trauma, such as school professionals (Mori et al., 2007), physical educators (de Oliveira et al., 2017) and sports participants (Mori et al., 2009), demonstrate faulty knowledge about management conducts.

Most professionals did not know that they could perform the replantation at the time of care or were not able to, did not know the ideal time to perform the replantation, how to properly manipulate the tooth and whether there was need for cleaning before replantation. These results corroborate other findings in the literature in which it was observed that most emergency (Lin et al., 2006; Traebert et al., 2009; Trividy et al., 2012; Ulusoy et al., 2012; Jetro et al., 2013; Needleman et al., 2013; Yigit et al., 2019) or felt little able to perform the replantation (Trividy et al., 2012).

It is known that when replantation is performed right after dental avulsion (up to 15 minutes) or when the tooth is stored in appropriate solutions to provide cell recovery, the prognosis of the tooth is increased (Mori et al., 2007). When immediate replantation is not possible, keeping the tooth in a humid environment is obligatory (Andersson et al., 2012). Milk is indicated as a storage medium of choice to avulsed teeth in many countries once it is available immediately, besides to preserve cell viability for up to 6 hours (Blomlöf et al., 1983; Pearson et al., 2003; Arikan et al., 2012; Mori et al., 2016). Lack of knowledge can negatively influence or the primary care of emergency services in case of dental avulsion.

Several studies have shown that there is a need for education of emergency professionals so that appropriate primary care can be provided by the patient in case of dental trauma (Lin et al., 2006; Traebert et al., 2009; Trividy et al., 2012; Ulusoy et al., 2012; Jetro et al., 2013; Needleman et al., 2013; Yigit et al., 2019). Furthermore, these studies reinforce that the lack of training and guidance may be the cause of emergency professionals do not feel safe to perform the replantation at the time of care (Lin et al., 2006; Traebert et al., 2009; Trividy et al., 2012; Needleman et al., 2013). One study also suggested that dental institutions should provide a list of dentists who are available 24 hours a day to provide first-time dental trauma care (Needleman et al., 2013). However, only one of these studies offered campaign or instructions to these professionals after finding that their knowledge was unsatisfactory (Cruz-da-Silva et al., 2016). Thus, the results of the present study corroborate other data from the literature that has demonstrated the importance not only of identifying the lack of knowledge of the population about the conducts to be performed in case of dental trauma, but also of the education of the professionals involved with dental trauma (Mori et al., 2007; Arikan et al., 2012; Taranath et al., 2017) such as educators, sportsmen, dentists, pediatricians and first responders.

Some authors (Cruz-da-Silva et al., 2016) performed a study similar to the present, evaluating the effects of an educational program on the level of knowledge of emergency medical service professionals in the city of Campina Grande (PB, Brazil). The authors also applied a questionnaire about dental trauma before and after the educational program. The authors observed a significant increase in the number of correct questions about the care to be taken in case of dental trauma. Results observed by Cruz da Silva et al. (2016) corroborate the findings of the present study, where a significant increase in the knowledge of professionals regarding the possibility (from $74 \%$ to $88 \%$ ) and ability (5\% to 32\%) of first responder to replace a avulsed tooth was observed; about the ideal time to perform the replantation (from 30\% to 59\%); about the correct handling (from $52 \%$ to $85 \%$ ) and the need for cleaning (from $60 \%$ to $79 \%$ ) of an avulsed tooth before replantation.

In the present study, no statistically significant difference was observed only regarding to the indication of the appropriate professional to provide emergency care, if it cannot be immediately performed by the first responder. The desirable answer to this question would be to refer you to the dentist closest to the scene of the accident or to the victim's dentist so that 
the replantation could be performed as quickly as possible. However, most professionals responded that they would refer the victim to a public hospital in the city. In this context, it is important to consider that professionals reported that they are required to refer their patients to hospitals, which certainly influenced these results.

An interesting event observed by evaluating the literature was that most studies that evaluated the knowledge of emergency service professionals about the correct conduct in dental trauma cases addressed doctors and the emergency team offered by hospitals (paramedics, nurses and even dentists). Only one study (Jetro et al., 2013) evaluated the level of knowledge of firefighters in case of dental trauma. Jetro et al. applied questionnaires to firefighters in the city of Caicó (RN, Brazil) and concluded that the knowledge of the professionals was unsatisfactory. The authors reinforced the need for guidance of these professionals but, again, no educational action was taken after the application of the questionnaires.

The limitations of this study include:

1) the number of individuals - which was the majority of emergency professionals in the city but who make up a small sample;

2) the educational campaign was carried out in small groups and not for all participants, due to the work scale of individuals who may have influenced the motivation to seek knowledge;

3) there was a small loss of sample between the first and second application of the questionnaire;

4) little time between the educational campaign and the time for the second application of the questionnaire due to the difficulty of access to the participants and their work scale.

\section{Conclusion}

There is a lack of knowledge of emergency service professionals about tooth avulsion management. The strong message is the importance not only of identifying the lack of knowledge of the professionals about tooth injuries, but also perform the education that can significantly improve the professional knowledge.

\section{References}

Ain, T. S., Lingesha Telgi, R., Sultan, S., Tangade, P., Ravishankar Telgi, C., Tirth, A., Kumar Pal, S., Gowhar, O., \& Tandon, V. (2016). Prevalence of Traumatic Dental Injuries to Anterior Teeth of 12-Year-Old School Children in Kashmir, India. Archives of trauma research, 5(1), e24596. https://doi.org/10.5812/atr.24596

Andersson, L., Andreasen, J. O., Day, P., Heithersay, G., Trope, M., Diangelis, A. J., Kenny, D. J., Sigurdsson, A., Bourguignon, C., Flores, M. T., Hicks, M. L., Lenzi, A. R., Malmgren, B., Moule, A. J., Tsukiboshi, M., \& International Association of Dental Traumatology (2012). International Association of Dental Traumatology guidelines for the management of traumatic dental injuries: 2. Avulsion of permanent teeth. Dental traumatology: official publication of International Association for Dental Traumatology, 28(2), 88-96. https://doi.org/10.1111/j.1600-9657.2012.01125.x

Andersson, L., \& Bodin, I. (1990). Avulsed human teeth replanted within 15 minutes--a long-term clinical follow-up study. Endodontics \& dental traumatology, 6(1), 37-42. https://doi.org/10.1111/j.1600-9657.1990.tb00385.x

Arikan, V., \& Sönmez, H. (2012). Knowledge level of primary school teachers regarding traumatic dental injuries and their emergency management before and after receiving an informative leaflet. Dental traumatology: official publication of International Association for Dental Traumatology, 28(2), 101-107. https://doi.org/10.1111/j.1600-9657.2011.01042.x

Azami-Aghdash, S., Ebadifard Azar, F., Pournaghi Azar, F., Rezapour, A., Moradi-Joo, M., Moosavi, A., \& Ghertasi Oskouei, S. (2015). Prevalence, etiology, and types of dental trauma in children and adolescents: systematic review and meta-analysis. Medical journal of the Islamic Republic of Iran, 29 (4), 234.

Baginska, J., Rodakowska, E., Milewski, R., Wilczynska-Borawska, M., \& Kierklo, A. (2016). Polish school nurses' knowledge of the first-aid in tooth avulsion of permanent teeth. BMC Oral Health, 16:30.

Blomlöf, L., Lindskog, S., Andersson, L., Hedström, K. G., \& Hamımarström, L. (1983). Storage of experimentally avulsed teeth in milk prior to replantation. J Dent Res, 62:912-6.

Cruz-da-Silva, B. R., Perazzo, M., Neves, É. T., Firmino, R. T., \& Granville-Garcia, A. F. (2016). Effect of an Educational Programme on the Knowledge Level Among an Emergency Service Medical Team Regarding Tooth Avulsion. Oral health \& preventive dentistry, $14(3)$, 259-266. https://doi.org/10.3290/j.ohpd.a35615

de Oliveira, D. L., Ribeiro-Junior, P. D., Sbroggio, A. C., Dos Santos, P. G., \& Mori, G. G. (2017). Evaluation of Knowledge of Physical Education Students on Dental Trauma. Annals of maxillofacial surgery, 7(2), 217-221. https://doi.org/10.4103/ams.ams_115_17

Flores, M. T., Andersson, L., Andreasen, J. O., Bakland, L. K., Malmgren, B., Barnett, F., Bourguignon, C., DiAngelis, A., Hicks, L., Sigurdsson, A., Trope, M., Tsukiboshi, M., von Arx, T., \& International Association of Dental Traumatology (2007). Guidelines for the management of traumatic dental injuries. II. 
Avulsion of permanent teeth. Dental traumatology: official publication of International Association for Dental Traumatology, 23(3), 130-136. https://doi.org/10.1111/j.1600-9657.2007.00605.x

Gonçalves, B. M., Dias, L. F., Pereira, C., Ponte, M. X., Filho, Konrath, A. C., Bolan, M., \& Cardoso, M. (2017). Impact of dental trauma and esthetic impairment on the quality of life of preschool children. Revista paulista de pediatria: órgão oficial da Sociedade de Pediatria de Sao Paulo, 35(4), 448-455. https://doi.org/10.1590/1984-0462/;2017;35;4;00011

Goyal, N., Singh, S., Mathur, A., Makkar, D. K., Aggarwal, V. P., Sharma, A., \& Kaur, P. (2017). Traumatic Dental Injuries Prevalence and their Impact on Self-esteem among Adolescents in India: A Comparative Study. Journal of clinical and diagnostic research: JCDR, 11(8), ZC106-ZC110. https://doi.org/10.7860/JCDR/2017/27496.10510

Jetro, V., Morais, H. H. A., Dias, T. G. S., Barbalho, J. C. M., \& Lucena, E. E. S. (2013). Traumatismo dentoalveolar: nível de conhecimento e conduta de urgência dos bombeiros do município de Caicó-RN. Rev Cir TraumatolBuco-Maxilo-Fac, 13(2):101-8.

Lin, S., Levin, L., Emodi, O., Fuss, Z., \& Peled, M. (2006). Physician and emergency medical technicians' knowledge and experience regarding dental trauma. Dental traumatology: official publication of International Association for Dental Traumatology, 22(3), 124-126. https://doi.org/10.1111/j.16009657.2006.00358.x

Matias, M., Fernandes, L. S., \& Araujo, M. M. (2014). Evaluation of the emergency procedure in cases of dental avulsion among different professionals in the city of São José dos Campos-SP. Braz dent sci, 17(2):35-41.

Mori, G. G., de Mendonça Janjácomo, D. M., Castilho, L. R., \& Poi, W. R. (2009). Evaluating the knowledge of sports participants regarding dental emergency procedures. Dental traumatology: official publication of International Association for Dental Traumatology, 25(3), 305-308. https://doi.org/10.1111/j.1600-9657.2009.00786.x

Mori, G. G., Nunes, D. C., Castilho, L. R., de Moraes, I. G., \& Poi, W. R. (2010). Propolis as storage media for avulsed teeth: microscopic and morphometric analysis in rats. Dental traumatology: official publication of International Association for Dental Traumatology, 26(1), 80-85. https://doi.org/10.1111/j.16009657.2009.00856.x

Mori, G. G., Castilho, L. R., Nunes, D. C., Turcio, K. H. L., \& Molina, R. O. (2007). Avulsion of permanent teeth: analysis of the efficacy of na informative campaign for professionals from elementary schools. Journal of Applied Oral Science, 15(6), 534-538. https://dx.doi.org/10.1590/S1678-77572007000600015

Mori, G. G., Turcio, K. H., Borro, V. P., \& Mariusso, A. M. (2007). Evaluation of the knowledge of tooth avulsion of school professionals from Adamantina, São Paulo, Brazil. Dental traumatology: official publication of International Association for Dental Traumatology, 23(1), 2-5. https://doi.org/10.1111/j.16009657.2005.00391.x

Needleman, H. L., Stucenski, K., Forbes, P. W., Chen, Q., \& Stack, A. M. (2013). Massachusetts emergency departments' resources and physicians' knowledge of management of traumatic dental injuries. Dental traumatology: official publication of International Association for Dental Traumatology, 29(4), 272-279. https://doi.org/10.1111/j.1600-9657.2012.01170.x

Pearson, R. M., Liewehr, F. R., West, L. A., Patton, W. R., McPherson, J. C., 3rd, \& Runner, R. R. (2003). Human periodontal ligament cell viability in milk and milk substitutes. Journal of endodontics, 29(3), 184-186. https://doi.org/10.1097/00004770-200303000-00005

Petti, S., Glendor, U., \& Andersson, L. (2018). World traumatic dental injury prevalence and incidence, a meta-analysis-One billion living people have had traumatic dental injuries. Dental traumatology: official publication of International Association for Dental Traumatology, 34(2), 71-86. https://doi.org/10.1111/edt.12389

Petrović, M., Kühl, S., Šlaj, M., Connert, T., \& Filippi, A. (2016). Dental and General Trauma in Team Handball. Swiss dental journal, 126(7-8), 682-686.

Taranath, M., Senaikarasi, R. M., \& Manchanda, K. (2017). Assessment of knowledge and attitude before and after a health education program in East Madurai primary school teachers with regard to emergency management of avulsed teeth. Journal of the Indian Society of Pedodontics and Preventive Dentistry, 35(1), 63-67. https://doi.org/10.4103/0970-4388.199218

Traebert, J., Traiano, M. L., Armênio, R., Barbieri, D. B., de Lacerda, J. T., \& Marcenes, W. (2009). Knowledge of lay people and dentists in emergency management of dental trauma. Dental traumatology: official publication of International Association for Dental Traumatology, 25(3), 277-283. https://doi.org/10.1111/j.1600-9657.2009.00779.x

Trivedy, C., Kodate, N., Ross, A., Al-Rawi, H., Jaiganesh, T., Harris, T., \& Anderson, J. E. (2012). The attitudes and awareness of emergency department (ED) physicians towards the management of common dentofacial emergencies. Dental traumatology: official publication of International Association for Dental Traumatology, 28(2), 121-126. https://doi.org/10.1111/j.1600-9657.2011.01050.x

Ulusoy, A. T., Onder, H., Cetin, B., \& Kaya, S. (2012). Knowledge of medical hospital emergency physicians about the first-aid management of traumatic tooth avulsion. Int J Paediatr Dent, 22(3):211-6.

Yigit, Y., Helvacioglu-Yigit, D., Kan, B., Ilgen, C., \& Yilmaz, S. (2019). Dentofacial traumatic injuries: A survey of knowledge and attitudes among emergency medicine physicians in Turkey. Dental traumatology: official publication of International Association for Dental Traumatology, 35(1), 20-26. https://doi.org/10.1111/edt.12440. 